\title{
A Study to Assess the Suicidal Behaviour among the Psychiatric Patients in a Tertiary Care Teaching Hospital, Guntur
}

\author{
Dr Vaddadi. Venkata kiran ${ }^{1}$, Dr. Neeli Uma Jyothi ${ }^{2}$, Mounica. Bollu ${ }^{3 *}$
}

Keywords: Suicidal Behaviour, Psychiatric Patients, Tertiary Care, Hospital, Guntur

Suicide attempt is a deliberate act of self harm with at least some intent of die that does not result in death. Such act has a wide range of medical seriousness. Individuals with psychiatric disorders are far more likely to commit suicide than the others. People who are psychologically disabled are often commit suicide from years of pain, frustration and depression. Spiritually they may perceive themselves as hopelessly damaged and lose all sense of purpose and meaning of life.

Suicide is not a diagnosis or a disorder. it is a behaviour. Suicide is a worldwide, national, local and familial problem. 90\% of people who kill themselves suffer from a diagnosable and preventable problem such as depression co-occurring mental and substance use disorders are common and potent combination among those who die by suicide.

Suicide has been recognised since early civilization. Hanging was a method frequently used before such tools as knives became commonplace. Attitudes towards suicide have shifted through the centuries as people gave names to feelings like shame and guilt. Suicide is now seen as an act with complex motivation and many contributing factors. It occurs in every culture, although at widely differing rates and is affected by cultural practices, expectations and values.

The threat to self concept or role performance causes some maladaptive behaviour in persons which in turn leads to self destructive behaviour. The incidence of suicidal behaviour is increasing day by day, the persons may commit suicide because of many reasons, psychosis is considered as a risk factor for the suicidal behaviour. Even though all the psychiatric patients do not commit suicide, it is considered as a leading cause. So, there is a need to identify the suicidal behaviour among the psychiatric patients.

\footnotetext{
${ }^{1}$ Assistant Professor, Department of psychiatry, Government general hospital, Guntur, India

${ }^{2}$ Associate Professor, Department of psychiatry, Government general hospital, Guntur, India

${ }^{3}$ Intern, Doctor of pharmacy, Department of pharmacy practice ,Government general hospital, Guntur, India

*Responding Author

(C) 2016, V Kiran, N Jyothi, M Bollu; licensee IJIP. This is an Open Access Research distributed under the terms of the Creative Commons Attribution License (http://creativecommons.org/licenses/by/2.0), which permits unrestricted use, distribution, and reproduction in any Medium, provided the original work is properly cited.
} 


\section{A Study to Assess the Suicidal Behaviour among the Psychiatric Patients in a Tertiary Care}

Teaching Hospital, Guntur

\section{CALLISTA ROY'S AND REW'S MODIFIED ADAPTATION THEORY}

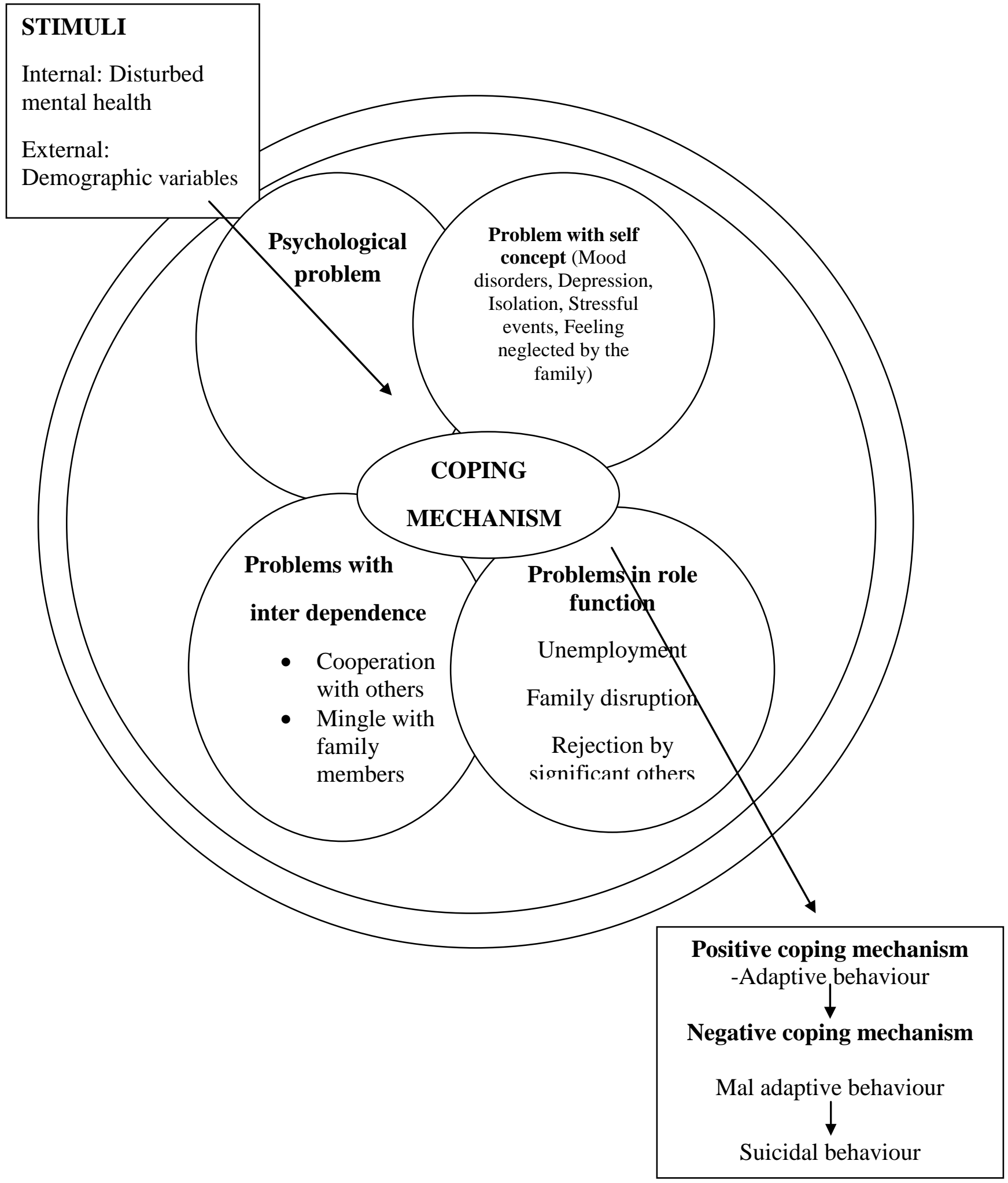

(c) The International Journal of Indian Psychology, ISSN 2348-5396 (e)| ISSN: 2349-3429 (p) | 130 


\section{A Study to Assess the Suicidal Behaviour among the Psychiatric Patients in a Tertiary Care Teaching Hospital, Guntur}

\section{Objective}

1. To identify the suicidal behaviour among the psychiatric patients

2. To find association between suicidal behaviour and selected demographic variable.

3. It was a non experimental descriptive study conducted using 60 patients suffering with psychiatric illnesses. Pilot study was conducted using 10 psychiatric patients.

\section{Description of the Data Collection Tool}

The data collection tool consists of two sections

SECTION-A: Demographic characteristics such as age, sex, education, occupation, social aspects of living, marital status, family history of suicide, history of hospitalization, informers, income levels.

SECTION-B: A checklist consists of 25 items regarding suicidal behaviour among the psychiatric patients. Each item has 2 options YES/NO. Each yes response carries a score of 1 and no responses carries a score of zero. Thus for 25 items there is a 25 maximum obtainable score.

\section{Scoring the Suicidal Behaviour among the Psychiatric Patients}

\begin{tabular}{|l|l|l|}
\hline Risk of suicidal behaviour & Score & Actual score \\
\hline Severe suicidal behaviour & $>75 \%$ & $19-25$ \\
\hline Moderate suicidal behaviour & $50-75 \%$ & $13-18$ \\
\hline Mild suicidal behaviour & $25-50 \%$ & $7-12$ \\
\hline No suicidal behaviour & $<25 \%$ & $0-6$ \\
\hline
\end{tabular}

\section{RESULTS}

Data was collected and analyzed, interpreted by using inferential statistics i.e., chi square test and descriptive statistics such as frequency and percentage.

\section{SECTION-A: DEMOGRAPHIC DATA ANALYSIS}

The sample was taken from psychiatric patients of inpatient and outpatient departments by simple random sampling technique.

\section{Frequency and Percentage Distribution According To Age}

\begin{tabular}{|l|l|l|}
\hline Age & Frequency & Percentage \\
\hline $21-30$ & 28 & $46.7 \%$ \\
$31-40$ & 24 & $40 \%$ \\
$41-50$ & 2 & $3.3 \%$ \\
$51-60$ & 6 & $10 \%$ \\
\hline
\end{tabular}

(c) The International Journal of Indian Psychology, ISSN 2348-5396 (e)| ISSN: 2349-3429 (p) | 131 


\section{A Study to Assess the Suicidal Behaviour among the Psychiatric Patients in a Tertiary Care Teaching Hospital, Guntur}

Majority (46.7\%) of the psychiatric patients were in the age group of 21-30 years ,40\% belong to the age group of $31-40$ years,3.3\% of the subjects are in the age group of $41-50$ years and $10 \%$ having the age in between 51-60 years

Frequency and Percentage Distribution According To Sex

\begin{tabular}{|l|l|l|}
\hline Sex & Frequency & Percentage \\
\hline Male & 40 & $66.6 \%$ \\
Female & 20 & $33.4 \%$ \\
\hline
\end{tabular}

In the current study, most of the respondents were the males (66.6\%) and remaining (33.4\%) were the females.

Frequency and Percentage Distribution According To Education

\begin{tabular}{|l|l|l|}
\hline Education & Frequency & Percentage \\
\hline Illiterate & 16 & $26.8 \%$ \\
Primary school education & 24 & $40 \%$ \\
secondary school education & 12 & $20 \%$ \\
higher school education & 4 & $6.6 \%$ \\
college education & 4 & $6.6 \%$ \\
\hline
\end{tabular}

Frequency and Percentage Distribution According To Occupation

\begin{tabular}{|l|l|l|}
\hline Occupation & Frequency & Percentage \\
\hline House wife & 14 & $23.3 \%$ \\
Daily wages & 28 & $46.7 \%$ \\
Government employee & 0 & $0 \%$ \\
Private employee & 0 & $0 \%$ \\
Self employee & 18 & $30 \%$ \\
\hline
\end{tabular}

Frequency and Percentage Distribution According To Social Aspects Of Living

\begin{tabular}{|l|l|l|}
\hline Social aspects of living & Frequency & Percentage \\
\hline Living alone & 6 & $10 \%$ \\
With family & 54 & $90 \%$ \\
With friends & 0 & $0 \%$ \\
Orphanages & 0 & $0 \%$ \\
\hline
\end{tabular}

Highest percentage(40\%) of patients have primary school education where as $26.8 \%$ were illiterates ,12(20\%) have secondary school education. most of the study participants (46.7\%) work as daily labour and $90 \%$ were living with their families. many of them (33.3\%) were separated .

(c) The International Journal of Indian Psychology, ISSN 2348-5396 (e)| ISSN: 2349-3429 (p) | 132 
A Study to Assess the Suicidal Behaviour among the Psychiatric Patients in a Tertiary Care Teaching Hospital, Guntur

Frequency and Percentage Distribution According To Marital Status

\begin{tabular}{|l|l|l|}
\hline Marital status & Frequency & Percentage \\
\hline Married & 15 & $25 \%$ \\
Unmarried & 6 & $10 \%$ \\
Widow & 11 & $18.3 \%$ \\
Separated & 20 & $33.3 \%$ \\
Divorced & 8 & $13.3 \%$ \\
\hline
\end{tabular}

Frequency and Percentage Distribution According To Family History Of Suicide

\begin{tabular}{|l|l|l|}
\hline Family history of suicide & Frequency & Percentage \\
\hline Yes & 32 & $53.3 \%$ \\
No & 28 & $46.6 \%$ \\
\hline
\end{tabular}

Frequency and Percentage Distribution According To Monthly Family Income

\begin{tabular}{|l|l|l|}
\hline Monthly family income & Frequency & Percentage \\
\hline $1000-5000$ & 16 & $26.7 \%$ \\
$5001-10000$ & 34 & $56.7 \%$ \\
$>10,000$ & 10 & $16.6 \%$ \\
\hline
\end{tabular}

Frequency and Percentage Distribution According To Informer

\begin{tabular}{|l|l|l|}
\hline Information received from & Frequency & Percentage \\
\hline Parents & 40 & $66.7 \%$ \\
Life partners & 8 & $13.3 \%$ \\
Siblings & 4 & $6.6 \%$ \\
Other relatives & 8 & $13.3 \%$ \\
\hline
\end{tabular}

Frequency and Percentage Distribution According To Type Of Illness

\begin{tabular}{|l|l|l|}
\hline Type of illness & Frequency & Percentage \\
\hline Depression & 12 & $20 \%$ \\
Bipolar & 8 & $13.3 \%$ \\
Schizophrenia & 12 & $20 \%$ \\
Alcoholism with associated & 20 & $33.4 \%$ \\
psychiatric disturbances & & \\
Psychosis & 8 & $13.3 \%$ \\
\hline
\end{tabular}

42(70\%) of psychiatric patients are having the family history of suicide. many of the participants (56.7\%) have the monthly income of rs.5000-10,000/-most (66.7\%) of the patients are presenting with their parents as their informers. According to this study, alcoholic patients with

(c) The International Journal of Indian Psychology, ISSN 2348-5396 (e)| ISSN: 2349-3429 (p) | 133 


\section{A Study to Assess the Suicidal Behaviour among the Psychiatric Patients in a Tertiary Care Teaching Hospital, Guntur}

associated psychiatric disturbances are more prone to suicide than patients with schizophrenia , bipolar and depression.

\section{SECTION -B:}

Item Wise Distribution of Psychiatric Patients According To the Suicidal Behaviour

\begin{tabular}{|c|c|c|c|}
\hline \multirow[t]{2}{*}{ S.NO } & \multirow[t]{2}{*}{ ITEMS } & \multicolumn{2}{|c|}{$\begin{array}{l}\text { Total no. of patients answered } \\
\text { YES }\end{array}$} \\
\hline & & Frequency & Percentage \\
\hline 1. & The patients has desperation and guilt & 32 & $53.3 \%$ \\
\hline 2. & Patient has history of aggression and violence & 40 & $66.6 \%$ \\
\hline 3. & $\begin{array}{l}\text { Patients showed withdrawal from relationship and } \\
\text { become isolated }\end{array}$ & 36 & $60 \%$ \\
\hline 4. & The patient is in sad depressive mood & 50 & $83.3 \%$ \\
\hline 5. & $\begin{array}{l}\text { The patient has lack of concentration in doing } \\
\text { activities }\end{array}$ & 52 & $86.6 \%$ \\
\hline 6. & The patient sleeps too much or too little & 42 & $70 \%$ \\
\hline 7. & $\begin{array}{l}\text { The patient has lack of interest in personal } \\
\text { appearance }\end{array}$ & 34 & $56.6 \%$ \\
\hline 8. & $\begin{array}{l}\text { The patient declined interest in friends or activities } \\
\text { previously enjoyed }\end{array}$ & 42 & $70 \%$ \\
\hline 9. & The patient has hopelessness & 40 & $66.6 \%$ \\
\hline 10. & The patient has self hatred & 38 & $63.3 \%$ \\
\hline 11. & $\begin{array}{l}\text { The patient showed sudden interest in personal will } \\
\text { or insurance }\end{array}$ & 0 & $0 \%$ \\
\hline 12. & $\begin{array}{l}\text { The patient passing negative statements such as "i } \\
\text { want to die”," this is the last time you will see me “" }\end{array}$ & 28 & $46.6 \%$ \\
\hline 13. & Patient wrote suicidal note & 6 & $10 \%$ \\
\hline 14. & $\begin{array}{l}\text { Obtained a weapon such as knife, collection of pills } \\
\text { from the patient }\end{array}$ & 14 & $23.3 \%$ \\
\hline 15. & The patient has history of suicide attempt & 18 & $30 \%$ \\
\hline 16. & The patient is always talking about suicide & 16 & $26.6 \%$ \\
\hline 17. & $\begin{array}{l}\text { The patient has sudden interest in activities after a } \\
\text { long period of depression }\end{array}$ & 18 & $30 \%$ \\
\hline 18. & The patient knows about his psychiatric disorder & 50 & $83.3 \%$ \\
\hline 19. & $\begin{array}{l}\text { The patient is found with suspicious circumstances } \\
\text { during night or day time eg: wandering outside, sitting } \\
\text { alone }\end{array}$ & 42 & $70 \%$ \\
\hline 20. & $\begin{array}{l}\text { The patient says that someone commanding him to } \\
\text { do suicide }\end{array}$ & 18 & $30 \%$ \\
\hline
\end{tabular}

(c) The International Journal of Indian Psychology, ISSN 2348-5396 (e)| ISSN: 2349-3429 (p) | 134 


\section{A Study to Assess the Suicidal Behaviour among the Psychiatric Patients in a Tertiary Care Teaching Hospital, Guntur}

\begin{tabular}{|c|c|c|c|}
\hline \multirow[t]{2}{*}{ S.NO } & \multirow[t]{2}{*}{ ITEMS } & \multicolumn{2}{|c|}{$\begin{array}{l}\text { Total no. of patients answered } \\
\text { YES }\end{array}$} \\
\hline & & Frequency & Percentage \\
\hline 21. & The patient comments suggests thoughts of suicide & 32 & $53.3 \%$ \\
\hline 22. & $\begin{array}{l}\text { The patient has uncharacteristic risk taking e.g., } \\
\text { reckless driving }\end{array}$ & 14 & $23.3 \%$ \\
\hline 23. & $\begin{array}{l}\text { The patient appearing overwhelmed by recent } \\
\text { stressor }\end{array}$ & 26 & $43.3 \%$ \\
\hline 24. & $\begin{array}{l}\text { The patient challenging people in an aggressive } \\
\text { manner }\end{array}$ & 22 & $36.6 \%$ \\
\hline 25. & $\begin{array}{l}\text { The patient displaying poor impulse control and } \\
\text { unusual behaviour }\end{array}$ & 30 & $50 \%$ \\
\hline
\end{tabular}

The above table of item wise distribution of suicidal behaviour of psychiatric patients shows that many of the psychiatric patients have lack of concentration in doing activities (86.6\%) and sad depressive mood is found in $83.3 \%$ of psychiatric circumstances, declined interest in friends or activities and disturbances. only $30 \%$ of psychiatric patients are having the history of previous suicide attempt where as one showed sudden interest in personal will on assurance.

Frequency and Percentage Distribution According To Level of Suicidal Behaviour

\begin{tabular}{|l|l|l|}
\hline Level of suicidal behaviour & Frequency & Percentage \\
\hline No suicidal behaviour & 6 & $10 \%$ \\
Mild suicidal behaviour & 20 & $33.3 \%$ \\
Moderate suicidal behaviour & 24 & $40 \%$ \\
Severe suicidal behaviour & 10 & $16.7 \%$ \\
& & \\
\hline
\end{tabular}

The above table shows that $6(10 \%)$ of patients have no suicidal behaviour, 20(33.3\%) have mild suicidal behaviour, $24(40 \%)$ of patients have moderate and 10(16.7\%) have high suicidal behaviour. overall 54(90\%) of patients with psychiatric disorders have suicidal behaviour.

(c) The International Journal of Indian Psychology, ISSN 2348-5396 (e)| ISSN: 2349-3429 (p) | 135 


\section{A Study to Assess the Suicidal Behaviour among the Psychiatric Patients in a Tertiary Care Teaching Hospital, Guntur}

Association of Suicidal Behaviour with the Demographic Variables among the Psychiatric Patients

Association of suicidal behaviour of psychiatric patients with age and sex

\begin{tabular}{|c|c|c|c|c|c|c|c|c|}
\hline \multirow{2}{*}{$\begin{array}{l}\text { Demographic } \\
\text { variable }\end{array}$} & \multirow{2}{*}{$\begin{array}{l}\text { No } \\
\text { suicidal } \\
\text { behaviour }\end{array}$} & \multirow{2}{*}{$\begin{array}{l}\text { Mild } \\
\text { suicidal } \\
\text { behaviour }\end{array}$} & \multirow{2}{*}{$\begin{array}{l}\text { Moderate } \\
\text { suicidal } \\
\text { behaviour }\end{array}$} & \multirow{2}{*}{$\begin{array}{l}\text { Severe } \\
\text { suicidal } \\
\text { behaviour }\end{array}$} & \multirow{2}{*}{$\begin{array}{l}\text { Degree } \\
\text { of } \\
\text { freedom }\end{array}$} & \multicolumn{2}{|c|}{ Chi square } & \multirow{2}{*}{$\begin{array}{l}\text { Level of } \\
\text { significance }\end{array}$} \\
\hline & & & & & & $\begin{array}{l}\text { Cal } \\
\chi^{2}\end{array}$ & $\begin{array}{l}\text { Tab } \\
\chi^{2}\end{array}$ & \\
\hline $\begin{array}{l}\text { Age in years } \\
21-30 \\
31-40 \\
41-50 \\
51-60\end{array}$ & $\begin{array}{l}1 \\
2 \\
0 \\
2\end{array}$ & $\begin{array}{l}12 \\
6 \\
0 \\
2\end{array}$ & $\begin{array}{l}13 \\
10 \\
2 \\
2\end{array}$ & $\begin{array}{l}2 \\
6 \\
0 \\
0\end{array}$ & 9 & 13.22 & 16.91 & NS \\
\hline $\begin{array}{l}\text { Sex } \\
\text { Male } \\
\text { Female }\end{array}$ & $\begin{array}{l}2 \\
4\end{array}$ & $\begin{array}{l}8 \\
12\end{array}$ & $\begin{array}{l}24 \\
0\end{array}$ & $\begin{array}{l}6 \\
4\end{array}$ & 3 & 4.36 & 7.81 & NS \\
\hline
\end{tabular}

Association of suicidal behaviour of psychiatric patients with education and occupation

\begin{tabular}{|c|c|c|c|c|c|c|c|c|}
\hline \multirow{2}{*}{$\begin{array}{l}\text { Demographic } \\
\text { variable }\end{array}$} & \multirow{2}{*}{$\begin{array}{l}\text { No } \\
\text { suicidal } \\
\text { behaviour }\end{array}$} & \multirow{2}{*}{$\begin{array}{l}\text { Mild } \\
\text { suicidal } \\
\text { behaviour }\end{array}$} & \multirow{2}{*}{$\begin{array}{l}\text { Moderate } \\
\text { suicidal } \\
\text { behaviour }\end{array}$} & \multirow{2}{*}{$\begin{array}{l}\text { Severe } \\
\text { suicidal } \\
\text { behaviour }\end{array}$} & \multirow{2}{*}{$\begin{array}{l}\text { Degree } \\
\text { of } \\
\text { freedom }\end{array}$} & \multicolumn{2}{|c|}{ Chi square } & \multirow{2}{*}{\begin{tabular}{|l|} 
Level \\
of \\
significance
\end{tabular}} \\
\hline & & & & & & $\begin{array}{l}\text { Cal } \\
\gamma^{2}\end{array}$ & $\begin{array}{l}\text { Tab } \\
\chi^{2}\end{array}$ & \\
\hline $\begin{array}{l}\text { Education } \\
\text { a. Illititerate } \\
\text { b.Primary } \\
\text { school } \\
\text { education } \\
\text { c.Secondary } \\
\text { school } \\
\text { education } \\
\text { d.Higher } \\
\text { secondary } \\
\text { education } \\
\text { e.College } \\
\text { education }\end{array}$ & $\begin{array}{l}3 \\
0 \\
1 \\
0 \\
0\end{array}$ & $\begin{array}{l}4 \\
8 \\
4 \\
0 \\
4\end{array}$ & $\begin{array}{l}7 \\
10 \\
7 \\
4 \\
0\end{array}$ & $\begin{array}{l}2 \\
6 \\
0 \\
0 \\
0\end{array}$ & 12 & 22.71 & 21.02 & Significant \\
\hline $\begin{array}{l}\text { Occupation } \\
\text { a.House wife } \\
\text { b.Daily wage } \\
\text { c.Government } \\
\text { employee } \\
\text { d.private } \\
\text { employee } \\
\text { e.self employee }\end{array}$ & $\begin{array}{l}0 \\
4 \\
0 \\
0 \\
0\end{array}$ & $\begin{array}{l}2 \\
8 \\
0 \\
0 \\
10\end{array}$ & $\begin{array}{l}10 \\
12 \\
0 \\
0 \\
6\end{array}$ & $\begin{array}{l}2 \\
4 \\
0 \\
0 \\
2\end{array}$ & 12 & 11.60 & 21.02 & NS \\
\hline
\end{tabular}

(C) The International Journal of Indian Psychology, ISSN 2348-5396 (e) | ISSN: 2349-3429 (p) | 136 
A Study to Assess the Suicidal Behaviour among the Psychiatric Patients in a Tertiary Care Teaching Hospital, Guntur

Association of suicidal behaviour of psychiatric patients with social aspects of living and marital status

\begin{tabular}{|c|c|c|c|c|c|c|c|c|}
\hline \multirow{2}{*}{$\begin{array}{l}\text { Demographic } \\
\text { variable }\end{array}$} & \multirow{2}{*}{$\begin{array}{l}\text { No } \\
\text { suicidal } \\
\text { behaviour }\end{array}$} & \multirow{2}{*}{$\begin{array}{l}\text { Mild } \\
\text { suicidal } \\
\text { behaviour }\end{array}$} & \multirow{2}{*}{$\begin{array}{l}\text { moderate } \\
\text { suicidal } \\
\text { behaviour }\end{array}$} & \multirow{2}{*}{$\begin{array}{l}\text { Severe } \\
\text { suicidal } \\
\text { behaviour }\end{array}$} & \multirow{2}{*}{$\begin{array}{l}\begin{array}{l}\text { Degree } \\
\text { of } \\
\text { freedom }\end{array} \\
\end{array}$} & \multicolumn{2}{|c|}{ Chi square } & \multirow{2}{*}{$\begin{array}{l}\text { Level } \\
\text { of } \\
\text { significance }\end{array}$} \\
\hline & & & & & & $\begin{array}{l}\text { Cal } \\
\chi^{2}\end{array}$ & $\begin{array}{l}\text { Tab } \\
\chi^{2}\end{array}$ & \\
\hline 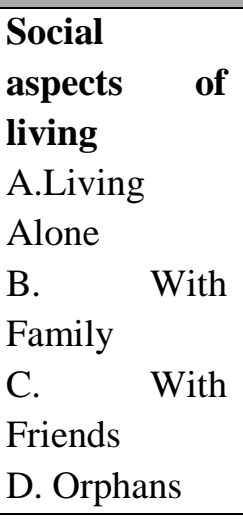 & $\begin{array}{l}0 \\
5 \\
0 \\
0\end{array}$ & $\begin{array}{l}0 \\
20 \\
0 \\
0\end{array}$ & $\begin{array}{l}4 \\
23 \\
0 \\
0\end{array}$ & $\begin{array}{l}2 \\
6 \\
0 \\
0\end{array}$ & 9 & 5.07 & 16.91 & NS \\
\hline $\begin{array}{l}\text { Marital } \\
\text { status } \\
\text { A.Married } \\
\text { B.Unmarried } \\
\text { C.Widow } \\
\text { D.Separated } \\
\text { E.Divorced }\end{array}$ & $\begin{array}{l}0 \\
0 \\
0 \\
2 \\
1\end{array}$ & $\begin{array}{l}8 \\
3 \\
3 \\
3 \\
1\end{array}$ & $\begin{array}{l}4 \\
2 \\
6 \\
10 \\
3\end{array}$ & $\begin{array}{l}3 \\
1 \\
2 \\
5 \\
3\end{array}$ & 12 & 12.83 & 21.06 & NS \\
\hline
\end{tabular}

Association of suicidal behaviour of psychiatric patients with family history of suicide and monthly family income

\begin{tabular}{|c|c|c|c|c|c|c|c|c|}
\hline \multirow{2}{*}{$\begin{array}{l}\text { Demographic } \\
\text { variable }\end{array}$} & \multirow{2}{*}{$\begin{array}{l}\text { No } \\
\text { suicidal } \\
\text { behaviour }\end{array}$} & \multirow{2}{*}{$\begin{array}{l}\text { Mild } \\
\text { suicidal } \\
\text { behaviour }\end{array}$} & \multirow{2}{*}{$\begin{array}{l}\text { moderate } \\
\text { suicidal } \\
\text { behaviour }\end{array}$} & \multirow{2}{*}{$\begin{array}{l}\text { Severe } \\
\text { suicidal } \\
\text { behaviour }\end{array}$} & \multirow{2}{*}{$\begin{array}{l}\text { Degree } \\
\text { of } \\
\text { freedom }\end{array}$} & \multicolumn{2}{|c|}{ Chi square } & \multirow{2}{*}{$\begin{array}{l}\text { Level } \\
\text { of } \\
\text { significance }\end{array}$} \\
\hline & & & & & & $\begin{array}{l}\text { Cal } \\
\chi^{2}\end{array}$ & $\begin{array}{l}\text { Tab } \\
\chi^{2}\end{array}$ & \\
\hline $\begin{array}{l}\text { Family history } \\
\text { of suicide } \\
\text { Yes } \\
\text { No }\end{array}$ & $\begin{array}{l}2 \\
4\end{array}$ & $\begin{array}{l}7 \\
14\end{array}$ & $\begin{array}{l}15 \\
6\end{array}$ & $\begin{array}{l}8 \\
4\end{array}$ & 3 & 4.27 & 7.81 & NS \\
\hline $\begin{array}{l}\text { Monthly } \\
\text { family income } \\
\text { a.Rs 1000- } \\
5000 /- \\
\text { b. Rs } 5000- \\
10000 /- \\
\text { c. Rs }>10000 /-\end{array}$ & $\begin{array}{l}2 \\
1 \\
2\end{array}$ & $\begin{array}{l}0 \\
16 \\
4\end{array}$ & $\begin{array}{l}10 \\
16 \\
2\end{array}$ & $\begin{array}{l}4 \\
1 \\
2\end{array}$ & 6 & 18.77 & 12.59 & Significant \\
\hline
\end{tabular}

(c) The International Journal of Indian Psychology, ISSN 2348-5396 (e)| ISSN: 2349-3429 (p) | 137 


\section{A Study to Assess the Suicidal Behaviour among the Psychiatric Patients in a Tertiary Care Teaching Hospital, Guntur}

Association of suicidal behaviour of psychiatric patients with informer and type of illness

\begin{tabular}{|c|c|c|c|c|c|c|c|c|}
\hline \multirow{2}{*}{$\begin{array}{l}\text { Demographic } \\
\text { variable }\end{array}$} & \multirow{2}{*}{$\begin{array}{l}\text { No } \\
\text { suicidal } \\
\text { behaviour }\end{array}$} & \multirow{2}{*}{$\begin{array}{l}\text { Mild } \\
\text { suicidal } \\
\text { behaviour }\end{array}$} & \multirow{2}{*}{$\begin{array}{l}\text { moderate } \\
\text { suicidal } \\
\text { behaviour }\end{array}$} & \multirow{2}{*}{$\begin{array}{l}\text { Severe } \\
\text { suicidal } \\
\text { behaviour }\end{array}$} & \multirow{2}{*}{$\begin{array}{l}\text { Degree } \\
\text { of } \\
\text { freedom }\end{array}$} & \multicolumn{2}{|c|}{ Chi square } & \multirow{2}{*}{$\begin{array}{l}\text { Level } \\
\text { of } \\
\text { significance }\end{array}$} \\
\hline & & & & & & $\begin{array}{c}\text { Cal } \\
\chi^{2}\end{array}$ & $\begin{array}{c}\text { Tab } \\
2^{2}\end{array}$ & \\
\hline $\begin{array}{l}\text { Informer } \\
\text { A.Parent } \\
\text { B.Life } \\
\text { Partners } \\
\text { C.Siblings } \\
\text { D.Other } \\
\text { Activities }\end{array}$ & $\begin{array}{l}3 \\
0 \\
0 \\
0\end{array}$ & $\begin{array}{l}18 \\
2 \\
0 \\
2\end{array}$ & $\begin{array}{l}13 \\
6 \\
2 \\
6\end{array}$ & $\begin{array}{l}6 \\
0 \\
2 \\
0\end{array}$ & 9 & 21.52 & 16.91 & Significant \\
\hline $\begin{array}{l}\text { Type of } \\
\text { Illness } \\
\text { A.Depression } \\
\text { B.Bipolar } \\
\text { C. } \\
\text { Schizophrenia } \\
\text { D.Alcoholism } \\
\text { E.Psychosis }\end{array}$ & $\begin{array}{l}0 \\
2 \\
0 \\
2 \\
0\end{array}$ & $\begin{array}{l}2 \\
4 \\
2 \\
8 \\
2\end{array}$ & $\begin{array}{l}7 \\
2 \\
6 \\
6 \\
4\end{array}$ & $\begin{array}{l}3 \\
0 \\
4 \\
4 \\
2\end{array}$ & 12 & 27.63 & 21.02 & Significant \\
\hline
\end{tabular}

From the above tables, it was found that Age , Sex, occupation, social aspects of living , marital status ,family history of suicide is not significant in identifying the suicidal behaviour among the psychiatric patients .Education, monthly family income, informers, type of illness affect the suicidal behaviour of the patients.

\section{CONCLUSION}

Suicide is an act or instance of taking one's own life voluntary. in psychiatric practice, suicide threats and gestures are taken as an emergency. It may be a symptom of psychiatric syndromes such as depression, psychosis or mood disorders. Identification of suicidal behaviour among psychiatric patients can be helpful to prevent suicide. Health care professionals should educate the family members and can help in reducing and controlling the psychosocial problems.

\section{Acknowledgments}

The author appreciates all those who participated in the study and helped to facilitate the research process.

\section{Conflict of Interests}

The author declared no conflict of interests.

\section{REFERENCES}

Baumeister, R. F. (1990). Suicide as escape from self. Psychological Review, 97, 90-113. 


\section{A Study to Assess the Suicidal Behaviour among the Psychiatric Patients in a Tertiary Care Teaching Hospital, Guntur}

Beck, A. T. Dteer, B. A. Kovals, Garrison. B . Hopelessness and eventual suicide, a 10 year prospective study of patients hospitalized with suicidal ideation. American journal of psychiatry,1985,pg no: 559-563.

Dean, R. A., Miskimins, W., DeCook, R., Wilson, L. T., \& Maley, R. F. (1967). Prediction of suicide in a psychiatric hospital. Journal of Clinical Psychology, 23, 296-301.

Funahashi. T, Buki Y, Domony, Nishimura, T. Akehashi and sugiura. A clinical study on suicide among schizophrenics. psychiatry \& clini neuro sciences,2000 pg no: 173-179.

Hawton, Sutton. L, Haw. C, Sincliar. J \& Harris. L .Suicide and attempted suicide in bipolar disorder. journal of clinical psychiatry .2005 pg no:693-704

Johnson J. Resilience to suicidal intention in psychosis, Elsevier publication, behaviour research and therapy.2010.

Mann. J, Waternaux. C, Hass. G and Mallone k.m. Toward a clinical model of suicidal behaviour in psychiatric patients. American journal of psychiatry.1999.pg no : 181-189.

Neuringer, C. (1974). Attitudes toward self in suicidal individuals. Life Threatening Behavior, 4, 96-106.

Niraj ahuja. A short textbook of psychiatry . $6^{\text {th }}$ edition. jaypee brothers medical publishers,2002 pg no: 236-238.

Pallis, D. J., Barraclough, B. M., Levey, A. B., Jenkins, J. S., \& Sainsbury, P. (1982). Estimating suicide risk among attempted suicides: I. The development of new clinical scales. British Journal of Psychiatry, 141, 37-44.

Powell .J, Geddes. J, Hawton. K, Deeks. J \& Goldaire. M. Suicide in psychiatric hospital inpatient. The British journal of psychiatry .2000.pg no: 266-272.

Practice guideline for the assessment and treatment of patients with suicidal behaviors. Am $\mathrm{J}$ Psychiatry. 2003 Nov;160(11 Suppl):1-60.

Westefeld, J. S., Range, L. M., Rogers, J. R., Maples, M. R., Bromley, J. L., \& Alcorn, J. (2000). Suicide: An overview. Counseling Psychologist, 28(4), 445-510.

Yasuhiro Kishi, and Roger G. Kathol. Assessment of Patients Who Attempt Suicide. Prim Care Companion J Clin Psychiatry. 2002; 4(4): 132-136.

Zung, W. W. K., \& Moore, J. (1976). Suicide potential in a normal adult population. Psychosomatics, 17(1), 37-41.

How to cite this article: V Kiran, N Jyothi, M Bollu (2016), A Study to Assess the Suicidal Behaviour among the Psychiatric Patients in a Tertiary Care Teaching Hospital, Guntur, International Journal of Indian Psychology, Volume 3, Issue 4, No. 63, ISSN 2348-5396 (e), ISSN: 2349-3429 (p), DIP: 18.01.109/20160304, ISBN: 978-1-365-32518-2 